\title{
STUDI TENTANG KOMPETENSI PROFESIONAL GURU DI TK MUSLIMAT NU-1 PALANGKA RAYA TAHUN AJARAN 2019/202
}

\author{
Ema Madahwati \\ Program Studi PG PAUD FKIP Universitas Palangka Raya \\ Jl. H. Timang Komplek Kampus Tunjung Nyaho Palangka Raya \\ Email : emamadahwati28@gmail.com
}

\begin{abstract}
ABSTRAK
Kompetensi secara sederhana dapat diartikan sebagai kemampuan dalam melakukan suatu pekerjaan. Jadi kompetensi pendidik PAUD adalah sebagai kemampuan yang dimiliki oleh pendidik PAUD dalam melakukan pekerjaannya sebagai pendidik, pengajar, pembimbing, pelatih, dan pengevaluasi anak usia dini baik PAUD jalur formal maupun nonformal. Kompetensi profesional adalah kemampuan seseorang dalam penguasaan materi pembelajaran secara luas dan mendalam yang memungkinkan membimbing peserta didik, memenuhi standar kompetensi yang ditetapkan. ) kompetensi profesional terkait dengan kemampuan pendidik PAUD dalam menguasai bidang pengembangan. Kompetensi profesional pendidik PAUD antara lain: (1) Menguasai materi, struktur, konsep, dan pola pikir keilmuan yang mendukung bidang pengembangan yang diampu, (2) Menguasai standar kompetensi dan kompetensi dasar bidang pengembangan yang diampu, (3) Mengembangkan materi bidang pengembangan yang diampu secara kreatif, dan (4) Mengembangkan profesionalan secara berkelanjutan dengan melakukan tindakan reflektif.

Penelitian ini bertujuan untuk mengetahui kompetensi profesional guru dalam pelaksanaan pembelajaran di TK Muslimat NU-1 Palangka Raya. Jenis penelitian ini adalah kualitatif. Keabsahan data menggunakan uji kredibilitas triangulasi teknik yaitu dengan sumber yang sama dan teknik yang berbeda. Data dalam penelitian ini berhubungan dengan kegiatan pembelajaran guru di kelas. Teknik dan instrumen pengumpulan data diantaranya observasi, wawancara, dan dokumentasi. Hasil menunjukkan bahwa kompetensi profesional guru sudah maksimal karena telah memenuhi standar kompetensi profesional guru.
\end{abstract}

\section{Kata Kunci: Studi Tentang Kompetensi Profesional Guru}




\section{PENDAHULUAN}

Pendidikan merupakan sarana yang paling urgen dalam mengembangkan sumber daya manusia (SDM) dan watak bangsa (Nation Character Building). Harkat dan martabat suatu bangsa sangat ditentukan oleh mutu pendidikannya. Dalam konteks bangsa Indonesia, peningkatan mutu pendidikan merupakan sasaran pembangunan di bidang pendidikan nasional dan merupakan bagian integral dari upaya peningkatan kualitas manusia Indonesia secara menyeluruh (Mulyasa, 2005).

Pendidikan sangat penting dalam kehidupan kita, apalagi Pendidikan Anak Usia Dini (PAUD) pada hakikatnya adalah pendidikan yang diselenggarakan dengan tujuan memfasilitasi pertumbuhan dan perkembangan seluruh aspek kepribadian anak. Pada Undang-Undang Nomor 20 Tahun 2003 Tentang Pendidikan Nasional disebutkan bahwa pendidikan adalah usaha sadar dan terencana untuk mewujudkan suasana belajar dan proses pembelajaran agar peserta didik secara aktif dapat mengembangkan potensi dirinya untuk memiliki kekuatan spiritual keagamaan, pengendalian diri, kepribadian, kecerdasan, akhlak mulia serta keterampilan yang diperlukan dirinya, masyarakat, bangsa dan negara. Sementara itu, anak dapat diartikan dalam individu yang belum dewasa, sedangkan usia dini adalah rentang usia 0 hingga 6 tahun. Jadi PAUD dapat diartikan sebagai usaha sadar dan terencana untuk mewujukan suasana belajar dan proses pembelajaran kepada anak usia 0 hingga 6 tahun secara aktif dan kreatif agar memiliki kecerdasan emosional dan spiritual, serta kecerdasan intelektual yang diperlukan bagi dirinya, masyarakat bangsa dan negara.

PAUD memberikan kesempatan kepada anak untuk mengembangkan karakter atau kepribadiannya atau potensinya secara maksimal. Konsekuensinya lembaga PAUD harus menyediakan berbagai kegiatan yang dapat mengembangkan berbagai aspek perkembangan secara moral dan agama, kognitif, bahasa, sosial dan emosi, serta fisik motorik.

Profesional merupakan pekerjaan atau kegiatan yang dilakukan oleh seseorang dan menjadi sumber penghasilan kehidupan yang memerlukan keahlian, kemahiran, atau kecakapan yang memenuhi standar mutu atau norma tertentu serta memerlukan pendidikan profesi. Profesionalisme guru sering dikaitkan dengan tiga faktor yang cukup penting, yaitu kompetensi guru, sertifikasi guru, dan tunjangan profesi guru. Ketiga faktor tersebut disinyalir berkaitan erat dengan maju-mundurnya kualitas 
pendidikan di Indonesia. Guru profesional yang dibuktikan dengan kompetensi yang dimilikinya akan mendorong terwujudnya proses dan produk kinerja yang dapat menunjang kualitas pendidikan. Kompetensi secara sederhana dapat diartikan sebagai kemampuan dalam melakukan suatu pekerjaan. Jadi kompetensi pendidik PAUD adalah sebagai kemampuan yang dimiliki oleh pendidik PAUD dalam melakukan pekerjaannya sebagai pendidik, pengajar, pembimbing, pelatih, dan pengevaluasi anak usia dini baik PAUD jalur formal maupun nonformal.

Idealnya pendidik PAUD profesional adalah pendidik PAUD yang memiliki empat kompetensi, yaitu kompetensi pedagogik, kompetensi kepribadian, kompetensi sosial, dan kompetensi profesional. Dalam Iskandar Agung (2012) kompetensi profesional mengacu pada pengertian kemampuan penguasaan materi pembelajaran secara luas dan mendalam yang memungkinkan membimbing peserta didik/siswa memenuhi sandar kompetensi yang ditetapkan Standar Nasional Pendidikan. Kompetensi profesional adalah kemampuan seseorang dalam penguasaan materi pembelajaran secara luas dan mendalam yang memungkinkan membimbing peserta didik, memenuhi standar kompetensi yang ditetapkan.

Taman Kanak-Kanak (TK) Muslimat NU-1 yang terletak di jalan Bali No.19 Palangka Raya merupakan Taman Kanak-Kanak yang menjadi tujuan penelitian penulis. Taman Kanak-Kanak (TK) Muslimat NU-1 Palangka Raya, yang merupakan salah satu wadah pendidikan anak usia dini dalam membina anak untuk mempersiapkan pendidikan ke jenjang sekolah dasar dan sekolah yang pertama kali berdiri di lingkungan padat penduduk daerah pasar besar Kota Palangka Raya. TK Muslimat NU1 Palangka Raya merupakan pendidikan TK di bawah yayasan Bina Bakti Wanita Muslimat NU.

Pada saat penulis melakukan observasi lapangan di TK Muslimat NU-1 Palangka Raya, salah satu yang menjadi ketertarikan untuk melakukan penelitian adalah tentang kompetensi profesional guru pendidikan anak usia dini dengan menggunakan berbagai pengelolaan pendidikan, tetap konsisten sejak berdiri hingga sekarang melaksanakan pembelajaran yang berbasis islam, TK Muslimat NU-1 Palangka Raya merupakan TK yang sudah terakreditasi, banyak prestasi yang telah diraih yaitu dengan memenangkan lomba-lomba antar TK dan memiliki pengajar yang sesuai dengan bidangnya yaitu S-1 PAUD, untuk mengetahui sebuah informasi dan proses dalam 
mencapai sebuah akreditasi TK sehingga dapat digunakan untuk acuan dalam peningkatan kualitas pendidikan dalam sebuah sekolah.

\section{METODE PENELITIAN}

Metode yang digunakan dalam penelitian ini adalah metode penelitian deskritif kualitatif. Hal ini sesuai dengan tujuan penelitian untuk mengetahui kompetensi profesional guru TK Muslimat NU-1 Palangka Raya. Metode ini digunakan untuk mendapatkan gambaran suatu keadaan yang berlangsung sekarang, menurut Sugiyono (2014) metode penelitian kualitatif adalah metode penelitian yang digunakan untuk meneliti pada kondisi obyek yang alamiah, (sebagai lawannya adalah eksperimen) dimana peneliti adalah sebagai instrumen kunci, teknik pengumpulan data dilakukan secara triangulasi (gabungan), analisis data bersifat induktif, dan hasil penelitian kualikatif lebih menekan makna dari pada generalisasi.

Pada penelitian ini dilakukan beberapa kegiatan, yaitu:

1. Menyusun panduan wawancara dan daftar pengamatan (cheklist) atau observasi ;

2. Melakukan wawancara kepada guru, anak, dan kepala sekolah serta pengamatan langsung dikelas dalam proses pembelajaran untuk memperoleh data tentang kompetensi profesional guru dalam mengajar anak.

3. Melakukan analisis data yang berkenaan dengan itu, data dianalisis secara deskritif kualitatif.

Dalam penelitian ini peneliti menggunakan metode penelitian Kualitatif. Dalam penelitian kualitatif, peneliti menjadi instrumen, maksudnya yaitu penelitian kualitatif instrumennya adalah orang atau human instrument. Untuk dapat menjadi instrumen, maka peneliti harus memiliki bekal teori dan wawasan yang luas, sehingga mampu bertanya, menganalisis, memotret, dan mengkonstruksi obyek yang diteliti menjadi lebih jelas dan bermakna (Sugiyono, 2014).

Peneliti melakukan penelitian dari Bulan Agustus sampai dengan September 2019. Peneliti dalam hal ini bertindak sebagai instrumen data untuk mengolah dan menyimpulkan data yang diteliti. Maka peneliti disini bertindak sebagai instrumen kunci sekaligus pengumpulan data. Dengan melakukan observasi, peneliti dapat mengetahui dan memahami gambaran yang otentik dan utuh tentang subyek penelitian.

Lokasi penelitian adalah tempat dimana penelitian dilakukan, dimana peneliti menemukan keadaan sebenarnya dari objek yang diteliti untuk mendapatkan data yang 
valid, akurat, yang dioerlukan dalam penelitian.Penelitian ini dilaksanakan di TK Muslimat NU-1 di jalan Bali No.19 Palangka Raya. Subyek penelitian ini adalah Guruguru Tahun ajaran 2019/2020.

Data yang digunakan dalam penelitian ini ada dua macam, adapun data tersebut ialah; Data primer dalam penelitian ini adalah data yang diperoleh langsung dari lapangan. Data ini dapat diperoleh melalui pengalaman langsung maupun wawancara kepada informan berdasarkan pedoman wawancara yang dibuat peneliti. Pada penelitian ini data primer yang digunakan untuk mengetahui tentang kompetensi profesional guru yaitu dengan melakukan wawancara terhadap guru, kepala sekolah, dan anak, serta dengan hasil dokumentasi hasil belajar anak dan RPPH yang digunakan dalam pembelajaran. Data sekunder adalah data yang diperoleh dari bahan bacaan, seperti surat-surat, notulen rapat perkumpulan sampai dokumen-dokumen resmi dari berbagai instansi pemerintah yang terhubung dengan masalah penelitian. Hal ini sejalan dengan pendapat Sugiyono, 2015 yang menyatakan :" Data Skunder merupakan sumber yang tidak langsung memberikan data kepada pengumpulan data, misalnya lewat orang lain atau dokumen “(Sugiyono, 2015). Data sekunder dalam penelitian ini di dapat melalui peninggalan tertulis yang dilakukan dengan cara membaca buku-buku literatur, dokumen, dan tulisan yang dianggap peneliti berkenaan dengan permasalahan yang sedang diteliti.

Teknik pengumpulan data yaitu menggunakan triangulasi, yaitu diartikan sebagai teknik pengumpulan data yang bersifat menggabungkan dari berbagai teknik pengumpulan data dan sumber data yang telah ada. Bila peneliti mengumpulkan data yang sekaligus menguji kredibilitas data, yaitu mengecek krebilitas data dengan berbagai teknik pengumpulan data dan berbagai sumber data (Sugiyono, 2014). Triangulasi teknik, berarti peneliti menggunakan teknik pengumpulan data yang berbeda-beda untuk mendapatkan data dari sumber yang sama. Peneliti menggunakan observasi partisipatif, wawancara mendalam, dan dokumentasi dari sumber data yang sama dari sumber yang berbeda-beda dengan teknik yang sama (Sugiyono, 2014).

Dalam penelitian kualitatif, yang menjadi istrumen atau alat penelitian adalah peneliti itu sendiri. Oleh karena itu peneliti sebagai isntrumen juga harus "divalidasi" seberapa jauh peneliti kualitatif siap melakukan penelitian yang selanjutnya terjun kelapangan. Validasi terhadap peneliti sebagai instrumen meliputi validasi terhadap 
pemahaman metode penelitian kualitatif, penguasaan wawasan terhadap bidang yang diteliti, kesiapan peneliti untuk memasuki obyek penelitian, baik secara akademik maupun logistiknya. Yang melakukan validasi adalah peneliti sendiri, melalui evaluasi diri seberapa jauh pemahaman terhadap metode kualitatif, penguasaan teori dan wawasan terhadap bidang yang diteliti, serta kesiapan dan bekal memasuki lapangan (Sugiyono, 2014:15). Dalam penelitian kualitatif, yang menjadi istrumen atau alat penelitian adalah peneliti itu sendiri. Olh karena itu peneliti sebagai isntrumen juga harus "divalidasi" seberapa jauh peneliti kualitatif siap melakukan penelitian yang selanjutnya terjun kelapangan. Validasi terhadap peneliti sebagai instrumen meliputi validasi terhadap pemahaman metode penelitian kualitatif, penguasaan wawasan terhadap bidang yang diteliti, kesiapan peneliti untuk memasuki obyek penelitian, baik secara akademik maupun logistiknya. Yang melakukan validasi adalah peneliti sendiri, melalui evaluasi diri seberapa jauh pemahaman terhadap metode kualitatif, penguasaan teori dan wawasan terhadap bidang yang diteliti, serta kesiapan dan bekal memasuki lapangan (Sugiyono, 2014:15).

Tabel 1. Kisi-kisi Instrumen Kompetensi Profesional Guru

\begin{tabular}{|l|l|l|}
\hline \multicolumn{1}{|c|}{ Variabel } & \multicolumn{1}{|c|}{ Indikator kompetensi profesional } & Keterangan \\
\hline \multirow{5}{*}{$\begin{array}{l}\text { Kompetensi } \\
\text { Profesional }\end{array}$} & $\begin{array}{l}\text { Menelaah konsep dasar keilmuan bidang } \\
\text { matematika, sains, bahasa, studi sosial, seni dan } \\
\text { agama yang sesuai dengan kebutuhan, tahapan } \\
\text { perkembangan dan psikometrik anak usia dini. }\end{array}$ & \\
\cline { 2 - 4 } $\begin{array}{l}\text { Muslimat NU- } \\
\text { Rayangka }\end{array}$ & $\begin{array}{l}\text { Mengorganisasikan konsep dasar keilmuan sebagai } \\
\text { alat, aktivitas dan konten dalam pengembangan } \\
\text { anak usia dini. }\end{array}$ & \\
\cline { 2 - 4 } & $\begin{array}{l}\text { Merumuskan tujuan setiap kegiatan pengembangan. } \\
\text { Menganalisis perkembangan anak usia dini dalam } \\
\text { setiap bidang pengembangan. }\end{array}$ & \\
\cline { 2 - 5 } & $\begin{array}{l}\text { Memilih materi berbagai kegiatan pengembangan } \\
\text { sesuai dengan tingkat perkembangan anak usia } \\
\text { dini. }\end{array}$ & \\
\cline { 2 - 5 } & $\begin{array}{l}\text { Mengorganisasikan kegiatan pengembangan secara } \\
\text { kreatif sesuai dengan tingkat perkembangan anak } \\
\text { usia dini. }\end{array}$ & \\
\cline { 2 - 5 } & $\begin{array}{l}\text { Melakukan refleksi terhadap kinerja sendiri secara } \\
\text { terus menerus. }\end{array}$ & \\
\cline { 2 - 5 } & $\begin{array}{l}\text { Memanfaatkan hasil refleksi dalam rangka } \\
\text { peningkatan keprofesionalan. }\end{array}$ & \\
\hline
\end{tabular}

Sumber: Peraturan Menteri Pendidikan dan Kebudayaan Republik Indonesia Nomor 137 Tahn 2014 Tentang Standar Nasional Pendidikan Anak Usia Dini. 
Analisis data kualitatif adalah bersifat induktif, yaitu suatu analisis berdasarkan data yang diperoleh, selanjutnya dikembangkan menjadi hipotesis. Berdasarkan hipotesis yang dirumuskan berdasarkan data tersebut, selanjutnya dicarikan data lagi secara berulang-ulang sehingga selanjutnya dapat disimpulkan apakah hipotesis tersebut diterima atau ditolak berdasarkan data yang terkumpul. Berdasarkan data yang dapat dikumpulkan secara berulang-ulang dengan teknik triangulasi, ternyata hipotesis diterima, maka hipotesis tersebut berkembang menjadi teori (Sugiyono, 2014).

Uji keabsahan data dalam penelitian kualitatif meliputi uji, credibility (validityas interval), transferability (validitas eksternal), dependability (reliabilitas), dan confirmability (obyektivitas). Uji kreabilitas data atau kepercayaan terhadap data hasil penelitian kualitatif antara lain dilakukan dengan perpanjangan pengamatan, peningkatan ketekunan dalam penelitian, tringulasi, diskusi dengan teman sejawat, analisis kasus negatif, dan member check. Triangulasi teknik untuk menguji kredibilitas data dilakukan dengan cara mengecek data kepada sumber yang sama dengan teknik yang berbeda.

\section{HASIL DAN PEMBAHASAN}

Pelaksanaan penelitian ini dilakukan di TK Muslimat NU-1 Palangka Raya yang terdiri dari 8 orang guru dan 1 kepala sekolah. Pengambilan data pertama dilakukan dengan dokumentasi, dimana peneliti mengambil beberapa foto pada saat kegiatan pembelajaran berlangsung, selain itu berupa video saat proses pembelajaran, dan beberapa RPPH (Rencana Pelaksanaan Pembelajaran Harian) yang digunakan guru dalam pelaksanaan kegiatan pembelajaran di dalam kelas, setelah itu peneliti juga melakukan wawancara yang mengacu tentang kompetensi profesional guru saat mengajar, selanjutnya peneliti melakukan observasi dan untuk menyakinkan atau memfalidasikan hasil dokumen dan observasi maka dilakukan wawancara dengan guru.

Pertama terlihat bahwa guru di TK Muslimat NU-1 sudah memahami konsep dasar keilmuan PAUD yang mencakup matematika, sains, kognitif, bahasa, sosial dan emosional, nilai-nilai agama dan moral, serta seni yang sesuai dengan tahapan perkembangan anak ini sesuai dengan Undang-undang RI Nomor 14 Tahun 2005 tentang Guru dan Dosen Pasal 1 yaitu Ijasah S1 yang dimiliki oleh pendidik PAUD merepresentasikan atau setidaknya legalitas formal bahwa pendidik PAUD telah 
memiliki keahlian, kemahiran, dan kecakapan yang memenuhi standar Pendidikan Anak Usia Dini. Dengan keahlian, kemahiran, dan kecakapannya itulah pendidik PAUD menjadi pendidik profesional. Sebagai pendidik profesional, pendidik PAUD idealnya berperan dalam mendidik, mengajar, membimbing, melatih, dan mengevaluasi peserta didiknya.

Kedua guru-guru di TK Muslimat NU-1 memiliki tujuan pembelajaran dan juga mengembangkan potensi anak dengan kreatif. Dalam observasi yang peneliti lakukan peneliti menemukan bahwa guru-guru di TK Muslimat NU-1 mengembangkan potensi anak menggunakan media-media yang ada dikelas atau di sekolah juga membuat sendiri media-media untuk bahan ajar anak. Sebagai contoh guru membuat bentuk tubuh manusia menggunakan lilin dan membuat bentuk tubuh manusia menggunakan balok. Kemudian untuk tujuan pembelajaran tercantum dalam RPPH guru yang telah dipersiapkan guru sebelum proses belajar mengajar. Hal ini sesuai dengan yang ada di dalam Undang-Undang RI Nomor 14 Tahun 2005 tantang Guru dan Dosen Pasal 1 yaitu Pendidik PAUD sebagai perencana pembelajaran. Sebagai perencana pembelajaran, pendidik PAUD mendesain suatu kegiatan pembelajaran di KB, TK, atau RA. Idealnya, berbagai hal yang harus diperhatikan oleh pendidik PAUD dalam perencanaan ini adalah sebagai berikut:

1. Menetapkan tujuan pemeblajaran dan tema kegiatan pembelajaran.

2. Memilih dan menetapkan metode pembelajaran yang akan digunakan sesuai dengan tujuan dan tema yang dipilih.

3. Memilih dan menetapkan media dan sumber belajar yang sesuai dengan tujuan pembelajaran dan tema.

4. Mendesain strategi pembelajaran berdasarkan berbagai metode serta media dan sumber pembelajaran yang telah dipilih dan ditetapkan.

5. Menentukan bentuk asesmen pembelajaran untuk mengetahui pencapaian pertumbuhan dan perkembangan anak usia dini.

Ketiga guru-guru di TK Muslimat NU-1 selalu melakukan penilaian dan evaluasi terhadap setiap hasil belajar anak. hal tersebut sesuai dengan Undang-Undang RI Nomor 14 Tahun 2005 tantang Guru dan Dosen Pasal 1 yaitu Pendidik PAUD sebagai penilai pelajaran. Pendidik PAUD melakukan penilaian pembelajaran sesuai dengan instrumen asesmen pembelajaran yang telah dipilih dan ditetapkannya. Penilaian 
tersebut dapat dilakukan selama proses pembelajaran maupun setelah proses pembelajaran berakhir. Dengan kegiatan penilaian tersebut, pendidik PAUD dapat mengetahui ketercapaian tujuan pembelajaran tersebut menggambarkan ketercapaian tujuan pembelajaran tersebut menggambarkan ketercapaian pertumbuhan dan perkembangannya. Kemudian pendidik PAUD sebagai pengevaluasi lebih luas ketika ia melakukan kegiatan penilaian pembelajaran. Penilaian pembelajaran yang dilakukan oleh pendidik PAUD merupakan salah satu kegiatan evaluasi yang dilakukan oleh pendidik PAUD.

Keempat guru-guru di TK Muslimat NU-1 mengetahui dan diterapkan pembelajaran yang disesuaikan dengan standar pencapaian perkembangan anak dengan baik. Hal tersebut sesuai dengan Peraturan Mentri Pendidikan dan Kebudayaan Republik Indonesia Nomor 173 Tahun 2014 tentang Standar Nasional Pendidikan Anak Usia Dini pada Kompetensi Pendidik (Guru PAUD, Guru Pendamping, Guru Pendamping Muda) dalam kompetensi profesional guru PAUD yaitu merancang berbagai kegiatan pengembangan secara kreatif sesuai dengan tahapan perkembangan anak usia dini.

Kelima guru melakukan refleksi diri untuk mengembangkan potensinya. Dalam observasi yang peneliti lakukan, guru-guru di TK Muslimat NU-1 selalu melakukan refleksi diri untuk proses belajar mengajar lebih baik lagi. Guru merefleksi diri agar keesokan harinya lebih baik lagi, terkadang guru langsung spontan merefleksi diri saat terdapat kesalahan pada saat proses belajar mengajar. Hal ini sesuai dengan Peraturan Mentri Pendidikan dan Kebudayaan Republik Indonesia Nomor 173 Tahun 2014 tentang Standar Nasional Pendidikan Anak Usia Dini pada Kompetensi Pendidik (Guru PAUD, Guru Pendamping, Guru Pendamping Muda) dalam kompetensi profesional guru PAUD yaitu mengembangkan keprofesionalan secara refleksi terhadap kinerja sendiri secara terus menerus.

Keenam guru meningkatkan kemampuan dengan mengikuti kegiatan seperti seminar, pelatihan, dan workshop dan penerannya pada anak. Pada observasi dan wawancara yang peneliti lakukan guru-guru di TK Muslimat NU-1 sering mengikuti kegiatan seperti seminar, pelatihan, workshop dan studi banding dengan sekolah lain. Hal tersebut sesuai dengan Peraturan Mentri Pendidikan dan Kebudayaan Republik Indonesia Nomor 173 Tahun 2014 tentang Standar Nasional Pendidikan Anak Usia Dini 
pada Kompetensi Pendidik (Guru PAUD, Guru Pendamping, Guru Pendamping Muda) dalam kompetensi profesional guru PAUD yaitu Mengembangan keprofesionalan secara berkelanjutan dengan melakukan tindak reflektif.

1. Melakukan refleksi terhadap kinerja sendiri secara terus menerus.

2. Memanfaatkan hasil refleksi dalam rangka meningkatkan keprofesionalan.

Berdasarkan hasil dokumentasi dan observasi peneliti juga melakukan wawancara untuk memperkuat pengumpulan data dengan pertanyaan yang diberikan kepada responden :

1. Apakah guru mengetahui konsep dasar keilmuan yang mencakup matematika, sains, bahasa, sosem, nilai agama dan oral serta seni yang sesuai dengan tahapan perkembangan anak? dan bagaimana penerapannya pada anak?

Berdasarkan hasil wawancara yang dilakukan pada 4 orang guru dan 1 kepala sekolah tersebut bahwa guru-guru di TK Muslimat NU-1 mengetahui dan memahami konsep dasar keilmuan PAUD karena guru-guru pernah belajar dan mengikuti kegiatan seperti seminar, pelatihan, atau workshop tentang PAUD untuk mengembangkan pengetahuan tentang pembelajaran pada PAUD.

2. Apakah guru mengembangkan potensi anak dengan kreatif? Dan bagaimana cara guru mengembangkannya!

Berdasarkan hasil wawancara dengan semua guru bahwa guru-guru dan kepala sekolah di TK Muslimat NU-1 mengembangkan potensi anak dengan berbagai kegiatan yang tidak membuat anak bosan dan membuat media pembelajaran agar kegiatan belajar mengajar menarik dan tidak membosankan. Guru-guru saat pembelajaran jarang menggunakan LKS, guru lebih sering membuat media belajar sendiri. Sebagai contoh melalui nyanyian-nyanyian yang membuat anak senang mengikuti pembelajaran, bermain perang-perangan menggunakan media perisai dan mandau kardus, dan masih banyak lagi.

3. Apakah apakah guru pernah melakukan penilaian atau evaluasi terhadap hasil belajar anak setiap hari?

Berdasarkan pengakuan semua guru, guru-guru selalu melakukan penilaian dan evaluasi pada anak setiap hari. Ada dua dan bahkan tiga penilaian yang dilakukan guru, seperti penilaian yang dilakukan guru utama dikelas, penilaian pada buku kerja anak, dan penilaian yang dilakukan oleh wali kelas. Jadi kesimpulannya guru- 
guru di TK Muslimat NU-1 selalu melakukan penilaian dan evaluasi pada hasil belajar anak.

4. Apakah guruapakah guru dalam pembelajaran disesuaikan dengan standar pencapaian perkembangan anak?

Berdasarkan hasil wawancara yang dilakukan pada para guru dan kepala sekolahnya dapat disimpulkan bahwa guru-guru di TK Muslimat NU saat melakukan pembelajaran selalu disesuaikan dengan tahapan perkembangan anak usia dini yang mencakup 6 aspek perkembangan seperti kogniti, fisik motorik, bahasa, sosem, nam dan seni. Kemudian membedakan kegiatan dan bantuan yang diperlukan pada setiap kelompok usia. Jadi kesimpulannya kegiatan pembelajaran di TK Muslimat NU-1 disesuaikan dengen standar pencapaian perkembangan anak.

5. Apakah guru memiliki tujuan dalam mengembangkan kegiatan untuk anak? dan bagaimana cara guru menerapkan tujuan tersebut!

Berdasarkan hasil wawancara dengan guru-guru, bahwa guru-guru memiliki tujuan yang tertulis dalam RPPH yaitu pada materi pemebiasaan dan materi kegiatan untuk anak. Saat pembuatan RPPH guru sering berunding tentang kegiatan dan tujuan dari kegiatan tersebut. Agar tujuan pembelajarannya tercapai di setiap kelas dan kegiatan. Kesimpulannya guru-guru di TK Muslimat NU-1 memiliki tujuan pembelajaran yang tercantum dalam RPPH.

6. Apakah guru pernah melakukan refleksi diri untuk mengembangkan potensinya?

Pada hasil wawancara dengan keempat guru dan satu kepala sekolah, guru-guru selalu melakukan refleksi diri untuk proses pembelajaran yang lebih baik, baik dilakukan secara langsung atau dilakukan untuk kegiatan berikutnya agar pembelajaran berjalan sesuai dengan tujuan yang seharusnya dicapai anak setiap harinya. Kesimpulannya guru-guru di TK Muslimat NU-1 selalu melakukan refleksi diri unguk mencapai tujuan sesuai harapan dan perencanaan.

7. Apakah guru pernah meningkatkan kemampuan dengan mengikuti kegiatan seperti seminar, pelatihan, atau workshop?

Berdasarkan pengakuan dari guru-guru, semua guru sering mengikuti kegiatan seperti seminar, pelatihan, workshop, dan studi banding untuk mengembangkan kemampuan guru-guru. Sering juga guru mengikuti kegiatan gugus seperti KKG (Kelompok Kerja Guru) yang dilaksanakan sebualan sekali. Kemuan baru-baru ini 
juga mengikuti studi banding di Banjar Baru untuk meningkatkan kualitas sekolah. Jadi kesimpulannya guru-guru di TK Muslimat NU-1 sering mengikuti kegiatan seperti seminar, pelatihan, workshop dan studi banding dengan TK-TK di dalam kota dan luar kota.

8. Apakah guru menerapkan apa yang didapat pada saat kegiatan seperti seminar, pelatihan, workshop kepada anak? dan bagaimana cara guru menerapkannya!

Berdasarkan dari pengakuan guru-guru bahwa guru-guru sering mengikuti kegiatan seminar dan apa yang didapat dari kegiatan tersebut sering mereka terapkan, sebagai contoh seperti nyanyian baru, gerakan dan lagu baru, tentang kurikulum, model belajar, dan RPPH sekolah itu semua didapat dari kegiatan seperti seminar, pelatihan, workshop, dan studi banding. Tetapi penerapannya melalui perundingan dengan semua guru dan kepala sekolah apakah situasi dan kondisi memadai untuk menerapkan apa yang diperoleh tersebut. Jadi kesimpulannya guru menerapkan apa yang diperoleh tetapi perlu disesuaikan dengan keadaan sekolah, jika keadaan sekolah memadai maka akan diterapkan disekolah, namun juga keadaan sekolah tidak memadai maka tidak diterapkan di sekolah.

\section{KESIMPULAN}

Hasil studi tentang kompetensi profesional guru di TK Muslimat NU-1 Palangka Raya mendapatkan hasil bahwa kompetensi profesional guru sudah maksimal karena telah memenuhi standar kompetensi profesional guru. Adapun standar-standar kompetensi profesional guru yang telah terpenuhi yaitu; pertama, menelaah konsep dasar keilmuan bidang matematika, sains, bahasa, studi sosial, seni dan agama yang sesuai dengan kebutuhan, tahapan perkembangan dan psikometrik anak usia dini. Kedua mengorganisasikan konsep dasr keilmuan sebagai alat, aktivitas dan konten dalam pengembangan anak usia dini. Ketiga merumuskan tujuan setiap kegiatan pengembangan. Keempat menganalisis perkembangan anak usia dini dalam setiap bidang pengembangan. Kelima memilih materi berbagai kegiatan pengembangan sesuai dengan tingkat perkembangan anak usia dini. Keenam mengorganisasikan kegiatan pengembangan secara kreatif sesuai dengan tingkat perkembangan anak usia dini. Ketujuh Melakukan refleksi terhadap kinerja sendiri secara terus menerus. Kedelapan memanfaatkan hasil refleksi dalam rangka peningkatan keprofesionalan. 


\section{DAFTAR PUSTAKA}

Afrizal., (2014) Metode Penelitian Kualitatif, Jakarta: PT RajaGrafindo Persada

Agung, Iskandar., (2012) Menghasilkan Guru Kompeten dan Profesional, Jakarta: Be Media Indonesia

Alma, Buchari., (2014) Guru Profesional, Bandung: CV ALFABETA

Andy, Novan Wiyani., (2016) Konsep Dasar PAUD, Yogyakarta: Gava Media

Arifin, Zainal., (2014) Penelitian Pendidikan, Bandung: PT Remaja Rosdakarya Offset

Febrialismato. 2017. Analisis Kompetensi Profesional Guru PG PAUD Kabupaten Kampar Provinsi Riau. Skripsi. Riau: Universitas Riau.

Indrawan Rully dan R. Poppy yaniawati., (2016) Metodologi Penelitian, Bandung: PT Rafika Aditama

Sanjaya, Wina., (2013) Penelitian Pendidikan, Jakarta: Kencana Prenada Media Group

Sugiyono., (2014) Memahami Penelitian Kualitatif, Bandung: CV Alfabeta

Sulikah. 2018. Analisis Kompetensi Profesional Guru PAUD dalam pelaksanaan Pembelajaran di Kecamatan Kartasura. Skripsi. Surakarta: Universitas Muhammadiyah Surakarta.

Peraturan Menteri Pendidikan dan Kebudayaan Republik Indonesia Nomor 137 Tahun 2014 Tentang Standar nasional Pendidikan Anak Usia Dini

Pitrawati, dkk. 2016. Analisi Kompetensi Guru PAUD di Kecamatan Serasan Kabupaten Natuna. Skripsi. UNTAN.

Yuslam, dkk. 2017. Studi Tentang Kompetensi Guru PAUD Berkualifikasi Akademik Sarjana PG PAUD dan NonPG PAUD di PAUD Istiqomah Sambah Purbalingga. Skripsi. Purwokerto: IAIN Purwokerto.

Anggrenie, Dewi., 2019. Studi Tentang Kreativitas Guru TK Bina Karya Palangka Raya Tahun Ajaran 2018/2019. Skripsi. Palangka Raya: Universitas Palangka Raya. 